\title{
Isolation and Screening of Extracellular Protease Enzyme from Fungal Isolates of Soil
}

\author{
Abdalla Mohamed Abdullah Maitig, Mohamed A.M. Alhoot* and Kartikya Tiwari \\ International Medical School, Management and Science University, 40000 MSU Shah Alam, Selangor Darul \\ Ehsan, Malaysia.
}

\begin{abstract}
Protease is an enzyme that conducts proteolysis and receives high attention as the most important enzyme in many industries. The enzymes find applications in waste treatment, bioremediation process, detergents and leather industry. However, the search for microbial sources of novel proteases in natural diversity is a promising area of interest for researchers. In the present research work, protease producing microorganisms were isolated from soil samples collected from three different locations in Petaling Jaya region from soil surface and at depths of $15 \mathrm{~cm}$. The isolated organisms screened for their protease generating abilities by using the skim milk agar experiment. The isolates that gave high positive results in screening identified as Aspergillus sp., Rhizopus sp., Fusarium sp., and Mucor sp. by analyzing the colonies morphology and using lacto- phenol cotton blue (LPCB) staining technique. Among these isolates, Aspergillus sp. 14L3S which isolated from soil surface demonstrated the highest protease activity indicated by the clear zone around the colony which is incubated at room temperature and maintained a pH of about 6.0 for 96 hours. The results showed that among the isolates four fungi had great potential to be used for the production of protease enzymes and upscale for industrial production.
\end{abstract}

Keywords: Isolation, Protease, Skimmed milk, lacto- phenol cotton blue, Colony.

*Correspondence: malhoot@hotmail.com

(Received: 07 October 2018; accepted: 28 November 2018)

Citation: Abdalla Mohamed Abdullah Maitig, Mohamed A.M. Alhoot and Kartikya Tiwari, Isolation and Screening of Extracellular Protease Enzyme from Fungal Isolates of Soil, J Pure Appl Microbiol., 2018; 12(4):2059-2067. http://dx.doi.org/10.22207/ JPAM.12.4.42

C The Author(s) 2018. Open Access. This article is distributed under the terms of the Creative Commons Attribution 4.0 International License which permits unrestricted use, sharing, distribution, and reproduction in any medium, provided you give appropriate credit to the original author(s) and the source, provide a link to the Creative Commons license, and indicate if changes were made. 


\section{INTRODUCTION}

Animals, plants and microorganisms produce protease and have an important role in numerous physiological as well as pathological processes like catabolism of protein, cell growth and migration, blood clotting, estimates of tissue morphogenesis in development, tumor growth and metastasis, inflammation, hormone production, activation of zymogens, and the pharmacologically active peptides from the precursor protein, and that protein transport across the membrane (Sawant \& Nagendran., 2014; Souza et al.2015). Extracellular proteases help catalyzes the proteins hydrolysis in the form of minor peptides as well as amino acids for final cells immersion, forming a highly significant step in the nitrogen metabolic processes (Sabotiè \& Kos, 2012; Souza et al.2015).

According to a recent study, the vast majority of industrial enzymes currently used are hydrolytic in action, with the use of it in the degradation of natural materials. Protease enzyme remained the dominant type, because of the fact that it is used by the vast majority of the industries.

Proteases (peptidases or proteolytic enzymes) are a group of enzymes that catalyse the hydrolysis of peptide bonds (Aladdin et al., 2017). Protease has been categorized based on several standards, proteases are classified according to the position of the peptide bond cleaved into two major groups as exopeptidases and endopeptidases (El Enshasy et al., 2016; Prassas et al., 2015]. They can also be classified as the acidic range ( $\mathrm{pH} 2.0$ to 6.0$)$, neutral $(\mathrm{pH} 6.0$ to 8.0) or alkaline proteases ( $\mathrm{pH} 8.0$ to 13.0) (Souza et al., 2015; 10Aladdin et al., 2017)

By emphasis, there are a lot of merits and benefits while using different enzyme biocatalysts with conventional chemicals. Considering that, the most important achievement made by using biocatalysts in preceding periods is chemicalfree industrial processes that contribute to environmental degradation and pollutions (Xu et al., 2011; Sawant \& Nagendran, 2014; Kumar \& Jain 2017 ).

In other words, they are molecules with a higher amount of substrate specificity of biochemical processes that result in efficient product formation (Xu et al., 2011). For microbes and soil biological activity is considered an active medium with numerous microorganisms that exist in the soil, and they relied on a number of ecological factors (Willey et al., 2009).

The enzyme that carries out proteolysis is the protease which represents almost $60 \%$ of the total enzyme markets (Deng et al., 2010; (Xu et al., 2011; Sawant \& Nagendran., 2014; Kumar \& Jain 2017). This enzyme plays an important role in a variety of applications in the medicine formulations, detergents, leather industry (Paul et al., 2016), and other processes such as waste treatment (Savitha et al., 2011; Sawant \& Nagendran., 2014; Souza et al.2015). In addition, the protease has application in food processing, brewing, grain mashing, milk freezes enzyme used to turn milk into products like cheese, and in terms of changing the properties of viscoelastic dough in baking and the production of protein hydrolysates (Veloorvalappil et al., 2013; Kumar \& Jain 2017); Kumari et al., 2012).

In the microorganisms, which is the most common source of commercial enzymes due to the nature of their physiology and biochemistry, facile cultural conditions, and ease of manipulation of the cells. Moreover, the fungus is generally considered as a good strain for the production of protease enzymes. They are simpler to be regenerated from mold fermentation broth of the genus Aspergillus, Penicillium, and Rhizopus. They are very valuable for protease production (Vishwanatha et al. 2009; Kumar \& Jain 2017).

Fungal protease has attracted the attention of experts of environmental biotechnology since fungi can grow on low-cost substrates and secrete huge quantities of the enzyme into the culture medium. Production of fungal protease has advantages over bacterial protease as mycelium may be easily detached by filtration (Kumar \& Jain 2017; Souza et al.2015 Anitha \& Palanivel, 2012; Vishwanatha et al., 2010b; Anitha \& Palanivelu, 2013).

An early stage in the development of industrial fermentation process isolated different organisms for the production of protease in the large-scale (Germano et al., 2003). In the current investigation, the fungal protease is isolated from soil samples at the surface and a depth of $15 \mathrm{~cm}$ under a banana tree. 


\section{METHODOLGY Sample Collection}

The soil samples were collected from the surface of the soil and at a depth of about $15 \mathrm{~cm}$ and taken with the help of a sterilized hand trowel was used to collect about $100 \mathrm{~g}$ each of the top soil and depths according to Oyeleke et al., (2010). The hand trowel was applied perpendicular to the vertical surface of the profile (Azaz, 2003), where all soil samples were collected in a sealed plastic bag and labeled as sample L1, L2, and L3.

The samples were collected from Persiaran Tropicana Petaling Jaya Jalan BU 11/17 (L1) loring 14/47 Petaling Jaya (L2) behind Surau Assamad Jalan PJU 1A/4A- Petaling Jaya Malaysia (L3) as shown in table 1 , all the samples specially collected under the banana trees. The samples kept at 4 으 until process.

\section{Soil samples}

Soil samples of Persiaran Tropicana Petaling Jaya Jalan BU 11/17 (L1) were lowlying area and the soil saturated with moisture waterlogged, While other soil samples from loring 14/47 Petaling Jaya (L2) and behind Surau Assamad Jalan PJU 1A/4A-Petaling Jaya (L3) were sandy and dry.

\section{Isolation and purification of fungi}

The serial dilution technique are used for the isolation of fungi from the soil (Kutateladze et al., 2016; Waksman, 1922) The twenty-five grams of the soil samples were mixed with a solution 225 $\mathrm{ml}$ of $1 \%$ peptone water (Choudhary \& Jain, 2012a; Sharpley, 1966; Mohanasrinvasan et al., 2012) with some modification.

Five screw cap test tubes with nine $\mathrm{ml}$ distilled water were autoclaved and arranged into the laminar flow hood for further processing, and serial dilutions were made from $10^{-1}, 10^{-3}$, and $10^{-5}$. First, third and fifth dilution were used to obtain fungal colonies. Then one milliliter $(1 \mathrm{ml})$ of soil suspension from the third dilution was taken and spread on the Potato Dextrose Agar (PDA) media plates using a glass rod spreader, sterilized by dipping in $70 \%$ ethanol and flaming. The plates were incubated at room temperature $\left(27^{\circ} \mathrm{C}\right)$ for 5 days, after spreading (Oyeleke et al., 2010; Choudhary \& Jain, 2012).

A mixture of various soil-borne fungi was grown on PDA medium, and a single spore of each fungus transferred to new PDA medium, plate by a sterilized needle for isolation of pure culture. After ensuring purity, the cultures were subcultured on PDA plates and allowed to grow for a period of 5-7 days and subsequently stored at 4 으 as stock cultures (Cappuccino \& Sherman, 2008; Mohanasrinvasan et al., 2012).

\section{Potato dextrose agar (PDA) preparation}

Suspend $39 \mathrm{~g}$ of the Potato Dextrose Agar (PDA) medium (Oxoid, England) in $1000 \mathrm{ml}$ of distilled water. Autoclaved at $121^{\circ} \mathrm{C}$ for 15 minutes then poured into plates. The plates were sterilized in fume hood cabinet.

\section{Preparation of Skim Milk Agar (SMA)}

Skim milk agar medium (Oxoid, England) is used for primary screening of protease producing fungi by mixing $25 \mathrm{~g}$ of nonfat dry milk was mixed with $250 \mathrm{ml}$ of distilled water. The mixture was stirred thoroughly and autoclaved at $121^{\circ} \mathrm{C}$ for 15 $\min$. The $\mathrm{pH}$ of the medium adjusted by using the $\mathrm{pH}$ meter (OMEGA, England) maintained at $\mathrm{pH} 6$, the suspension of $2.5 \%$ agar (Oxoid, England) used for solidification were autoclaved at $121^{\circ} \mathrm{C}$ for $15 \mathrm{~min}$. For plating, skim milk and agar solutions were held in a water bath at $50^{\circ} \mathrm{C}$ and then the skim milk was poured into the agar flask and mixed thoroughly. To restrict the bacterial growth $1 \mathrm{mg} / 1000 \mathrm{ml}$ ampicillin (Duchefa Brochemie B.A, Netherlands) was added to the media. The skim milk agar was poured quickly into plates then kept at $4^{\circ} \mathrm{C}$ until used (Pailin et al., 2001; Mohanasrinvasan et al., 2012).

\section{Lacto phenol cotton blue}

Lactophenol Cotton Blue stain was used (Sigma-Aldrich, Germany) to study the microscopic characteristics of fungi, a drop of lactophenol solution was placed onto a clean slide. The needles were sterilized in the bunsen burner, the small amount of fungal culture was removed from the edge of the colony with taken a little of the agar medium together with the fungus. The fungal culture was spread onto a slide by using second needle in order to tease out the fungal structures. The needles sterilised in bunsen flame (Holt et al., 1994; Leck, 1999; Mohanasrinvasan et al., 2012).

\section{Screening for protease production}

Skim milk agar medium is used for screening of protease production by fungi (Namasivayam \& Nirmala, 2013; Ayob \& Simarani, 2016; Vijayaraghavan \& Vincent, 2013). The pure culture isolates were streak on the skim milk agar 
plates and incubated at room temperature $\left(27^{\circ} \mathrm{C}\right)$ for four days. Then the appearance of clear zone in the medium around the colony indicates protease activity. The zones diameter were measured in $\mathrm{mm}$ and results are recorded (Warcup, 1950; Abe et al., 2015). The enzymatic index (EI) expressed as $R / r$, which $R$ is the degradation zone diameter and $r$ is the colony diameter (Hankin \& Anagnostakis, 1975; Abe et al., 2015). The species that exhibits maximum clear zone selected for further identification.

\section{Identification of isolated fungi}

The isolated fungi were subcultured on PDA and allowed to grow and sporulation. Then from their colony and morphological characteristics, the fungi were identified. Lactophenol cotton blue stain used as the mounting fluid. The slides observed under the microscope then fungi were identified by following the mycological literature (Mohanasrinvasan et al., 2012; Bradner et al., 1999). The following morphological characteristics evaluated the colony growth (length, width, presence or absence of aerial mycelium, colony color, a presence of wrinkles and furrows, and pigment production) (Tarman et al., 2011). The characteristics were compared with the standard description in Bergey's manual of determinative bacteriology (Holt et al., 1994; Malloch, 1981).

\section{RESULTS}

The fungal isolates were isolated using PDA agar plates was incubated at room temperature $\left(27^{\circ} \mathrm{C}\right)$ for five days. Forty four (44) fungi were isolated from the soil samples as in Table 2. The isolates had different morphological characteristics, different colony colors and different colony sizes. The average incubation time was five days to observe the full growth on the agar plates. The total of 44 fungal isolates were isolated from different soils, collected from (L1) [Persiaran Tropicana Petaling Jaya Jalan BU 11/17] gives the highest isolates number of about 19 isolates (from surface with at depths $15 \mathrm{~cm}$ ), while location three (L3) [Jalan PJU 1A/4A- Petaling Jaya] which had 13 isolates and the lowest number of isolates studied at location two (L2) [loring 14/47 Petaling Jaya]. The surface of the soil showed the higher number of isolates in comparison with the $15 \mathrm{~cm}$ depth in the soil (Table 2).

Table 1. Different soil samples from Petaling Jaya.

\begin{tabular}{ll}
\hline Site & Code \\
\hline Persiaran Tropicana Petaling Jaya Jalan BU 11/17( surface) & L1S \\
Persiaran Tropicana Petaling Jaya Jalan BU 11/17, (15 cm depth) & L1D \\
loring 14/47 Petaling Jaya, (surface) & L2S \\
loring 14/47 Petaling Jaya, (15 cm depth) & L2D \\
Jalan PJU 1A/4A- Petaling Jaya (surface) & L3S \\
Jalan PJU 1A/4A- Petaling Jaya (15 cm depth) & L3D \\
\hline
\end{tabular}

Table 2. Location of soil samples

\begin{tabular}{|c|c|c|c|}
\hline Sample & $\begin{array}{l}\text { Number of } \\
\text { isolates }\end{array}$ & Location & $\begin{array}{l}\text { Percentage of } \\
\text { total isolates }\end{array}$ \\
\hline \multirow[t]{2}{*}{ L1S } & 11 & Persiaran Tropicana Petaling & \\
\hline & & Jaya Jalan BU 11/17 & $25 \%$ \\
\hline \multirow[t]{2}{*}{ L1D } & 8 & Persiaran Tropicana Petaling & \\
\hline & & Jaya Jalan BU $11 / 17$ & $18.18 \%$ \\
\hline L2S & 7 & loring 14/47 Petaling Jaya & $15 \%$ \\
\hline L2D & 5 & loring 14/47 Petaling Jaya & $11.36 \%$ \\
\hline L3S & 7 & Jalan PJU 1A/4A- Petaling Jaya & $15 \%$ \\
\hline L3D & 6 & Jalan PJU $1 \mathrm{~A} / 4 \mathrm{~A}$ - Petaling Jaya & $13 \%$ \\
\hline Totals & 44 & & \\
\hline
\end{tabular}

*S= soil surface, $D=15 \mathrm{~cm}$ depth in soil, L=location 
The fungal isolates were screened for their ability to produce protease enzymes. Majority of the isolates showed protease production activity as shown in Table 3. The maximum production observed after 96 hours. Based on the skim milk agar experiment for protease detection, total of eight isolates from the soil at $15 \mathrm{~cm}$ depth exhibited protease production activity while seven isolates from the surface produced high protease enzymes. Among the protease producing fungi, six were isolated from location two (loring 14/47 Petaling Jaya), five from location three (Jalan PJU $1 \mathrm{~A} / 4 \mathrm{~A}$ - Petaling Jaya), and four samples isolated from location one (Persiaran Tropicana Petaling Jaya Jalan BU 11/17). Isolate 14L3S demonstrated the highest protease activity followed by 6L1D,
$5 \mathrm{~L} 2 \mathrm{~S}$ and $9 \mathrm{~L} 2 \mathrm{D}$ as seen by the clear zone around the colonies (Figure 1). At 48 hours 14L3S isolate zone was $12.75 \mathrm{~mm}$ and increased to $15.75 \mathrm{~mm}$ after $72 \mathrm{hrs}$, then reached to $17 \mathrm{~mm}$ after $96 \mathrm{hrs}$. 17L1D did not show any protease production activity at $48 \mathrm{hrs}$, while the protease production started after $72 \mathrm{hrs}$ to finally reach $3.25 \mathrm{~mm}$ after $96 \mathrm{hrs}$.

Fungi 8L2D and 10L1D did not develop any significant increasing in the protease production from the $48 \mathrm{hrs}$ till $96 \mathrm{hrs}$. Fungi 9L2D protease activity increased more than $100 \%$ after 96 hrs of incubation. All the protease producing isolates showed clear zones around their colonies with variation in the diameters as in Table 3.
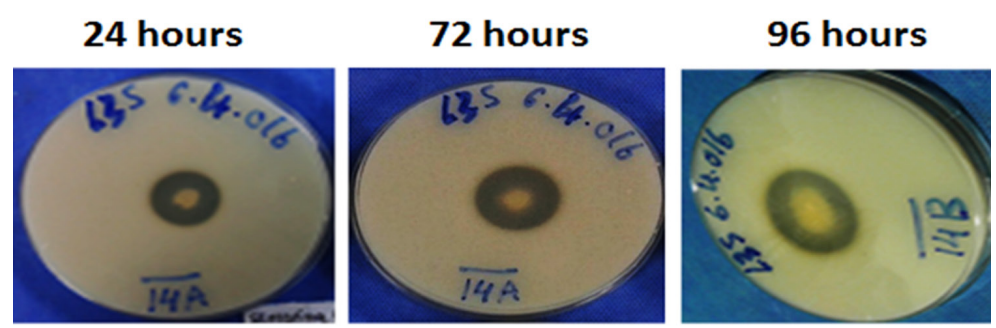

$\mathbf{A}$
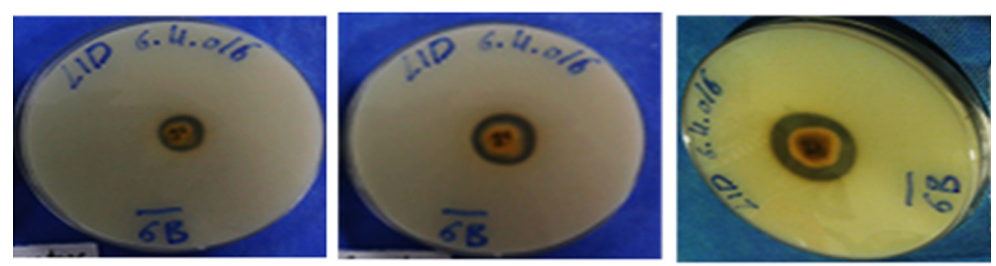

B
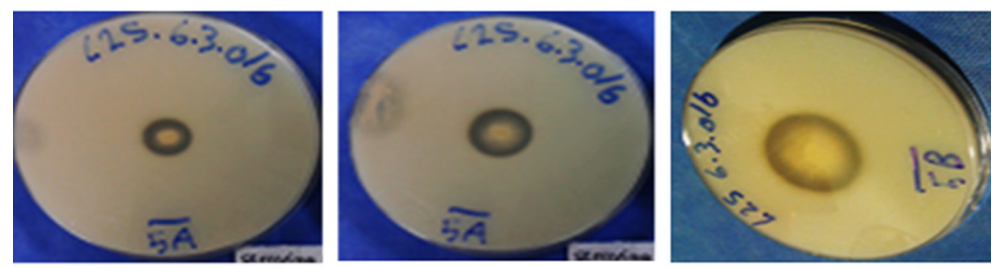

C
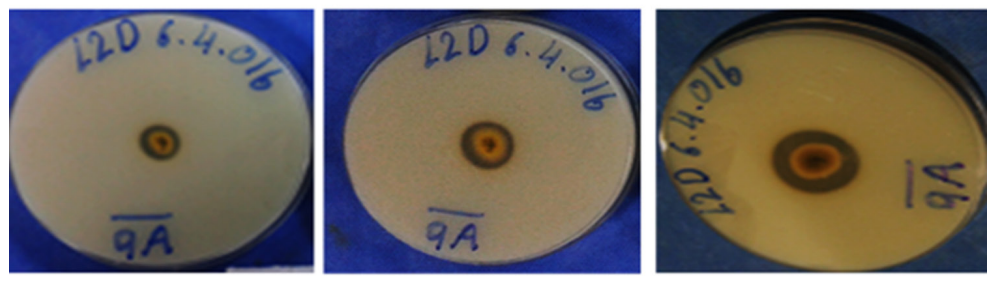

D

Fig. 1. Clearance Zone diameter around the fungal isolates A) 14L3S, B) 6L1D, C) 5L2S, and D) 9L2D. 
The enzyme activity was estimated by the presence of a clear zone around the colonies. Among 15 fungi which shows protease activity,

Table 3. Clearance zone diameter around the fungal colonies

\begin{tabular}{|c|c|c|c|}
\hline \multirow[t]{2}{*}{ Isolates } & \multicolumn{3}{|c|}{$\begin{array}{r}\text { Protease activity Diameter of the } \\
\text { Zone clearance }(\mathrm{mm})\end{array}$} \\
\hline & $48 \mathrm{hrs}$ & $72 \mathrm{hrs}$ & $96 \mathrm{hrs}$ \\
\hline $1 \mathrm{~L} 3 \mathrm{~S}$ & 3 & 4 & 4.5 \\
\hline 2L3D & 2.5 & 6.75 & 7.5 \\
\hline $3 L 2 D$ & 1.25 & 2.75 & 4.0 \\
\hline $4 \mathrm{~L} 2 \mathrm{D}$ & 2.75 & 3.25 & 4.75 \\
\hline $5 \mathrm{~L} 2 \mathrm{~S}$ & 6.25 & 8 & 11.5 \\
\hline 6L1D & 4 & 10 & 13.25 \\
\hline 8L2D & 6.5 & 7 & 7.0 \\
\hline 9L2D & 4.25 & 5 & 9.75 \\
\hline 10L1D & 2 & 2.25 & 2.5 \\
\hline $11 \mathrm{~L} 1 \mathrm{~S}$ & 3.5 & 3.75 & 7.0 \\
\hline $14 \mathrm{~L} 3 \mathrm{~S}$ & 12.75 & 15.75 & 17 \\
\hline $15 \mathrm{~L} 3 \mathrm{~S}$ & 1.75 & 1.75 & 2.0 \\
\hline 17L1D & 0 & 1.5 & 3.25 \\
\hline $18 \mathrm{~L} 2 \mathrm{~S}$ & 5.5 & 4.25 & 5.75 \\
\hline 19L3S & 3.5 & 4.5 & 3.0 \\
\hline
\end{tabular}

*S= soil surface, $\mathrm{D}=15 \mathrm{~cm}$ depth in soil, $\mathrm{L}=$ location the isolate 14 L3S exhibited the highest of enzyme activity (2.09) based on the ratio of diameter of clearing zone and colony, while the isolate 19 L3S showed the lowest activity (1.07) as in Table 4.

The fungal isolates from the different soil samples were examined by using the lactophenol cotton blue (LPCB) wet mount preparation method in compensation with their morphological characteristics. Out of 15 isolates that showed protease activity, four were identified as follows, 14L3S isolate identified as Aspergillus. sp, isolate 6L1D belonged to Rhizopus. $s p$, isolate $5 \mathrm{~L} 2 \mathrm{~S}$ belonged to Fusarium. $s p$, and isolate 9L2D identified as Mucor. sp (Table 5).

For the identification of isolated fungal species which shows highest production of extracellular protease were done based on macroscopic and microscopic characteristics as shown in isolate 14L3S as Aspergillus sp., isolate 6L1D Rhizopus sp, isolate 5L2S Fusarium sp, isolate 9L2D also Fusarium $s p$. The identified fungal samples are listed in table 5 .

The production of protease enzyme at different time, which shows the highest production by Aspergillus sp. at 96 hours followed by Rhizopus sp., Fusarium sp., Mucor sp.

Table 4. Enzyme index of the 15 positives isolated from surface and depths of soil

\begin{tabular}{|c|c|c|c|c|c|c|c|c|c|}
\hline \multirow[t]{3}{*}{ Isolates } & \multicolumn{3}{|c|}{$\begin{array}{c}\text { Clear zone } \\
\text { diameter }(\mathrm{mm})\end{array}$} & \multicolumn{3}{|c|}{$\begin{array}{c}\text { Colony } \\
\text { diameter }(\mathrm{mm})\end{array}$} & \multicolumn{3}{|c|}{$\begin{array}{l}\text { Enzyme index }(\mathrm{EI})= \\
\text { Clear zone diameter/ } \\
\text { Colony diameter }\end{array}$} \\
\hline & \multicolumn{9}{|c|}{ Incubation hours } \\
\hline & 48 & 72 & 96 & 48 & 72 & 96 & 48 & 72 & 96 \\
\hline $1 \mathrm{~L} 3 \mathrm{~S}$ & 13.5 & 17.5 & 24 & 10.5 & 13.5 & 19.5 & 1.3 & 1.29 & 1.23 \\
\hline $2 \mathrm{~L} 3 \mathrm{D}$ & 7.25 & 10.5 & 18 & 4.75 & 3.75 & 10.5 & 1.5 & 2.8 & 1.71 \\
\hline $3 L 2 D$ & 8.75 & 12 & 17 & 7.5 & 9.25 & 13 & 1.2 & 1.29 & 1.30 \\
\hline 4L2D & 11 & 15.75 & 23.25 & 8.25 & 12.5 & 18.5 & 1.3 & 1.26 & 1.29 \\
\hline $5 \mathrm{~L} 2 \mathrm{~S}$ & 13.5 & 19 & 29 & 7.25 & 11 & 18 & 1.9 & 1.72 & 1.61 \\
\hline 6L1D & 11 & 20.5 & 26 & 7.0 & 10.5 & 12.75 & 1.6 & 1.95 & 2.03 \\
\hline 8L2D & 13.75 & 21.25 & 35.5 & 7.25 & 14.25 & 28.5 & 1.9 & 1.49 & 1.24 \\
\hline $9 L 2 D$ & 12 & 16.75 & 23.5 & 7.75 & 11.75 & 13.75 & 1.5 & 1.42 & 1.70 \\
\hline 10L1D & 8.0 & 10.5 & 13.5 & 6.0 & 8.25 & 11.0 & 1.3 & 1.27 & 1.22 \\
\hline 11L1S & 10.5 & 15.75 & 26.75 & 7.0 & 12.0 & 19.75 & 1.5 & 1.31 & 1.35 \\
\hline $14 \mathrm{~L} 3 \mathrm{~S}$ & 19.25 & 24.75 & 32.5 & 6.5 & 9.0 & 15.5 & 3.0 & 2.75 & 2.09 \\
\hline $15 \mathrm{~L} 3 \mathrm{~S}$ & 7.25 & 11.25 & 16.25 & 5.5 & 9.5 & 14.25 & 1.3 & 1.18 & 1.14 \\
\hline 17L1D & 6.0 & 8.0 & 12.0 & 6.0 & 6.5 & 8.75 & $\mathrm{~N}$ & 1.23 & 1.37 \\
\hline $18 \mathrm{~L} 2 \mathrm{~S}$ & 15.75 & 20 & 28.75 & 10.25 & 15.75 & 23 & 1.5 & 1.26 & 1.25 \\
\hline 19L3S & 10.5 & 22.25 & 42 & 7.0 & 17.75 & 39 & 1.5 & 1.25 & 1.07 \\
\hline
\end{tabular}


Table 5. Identification of isolated fungi

\begin{tabular}{ll}
\hline Isolates code & Fungi \\
\hline 14L3S & Aspergillus sp. \\
6L1D & Rhizopus sp \\
5L2S & Fusarium $s p$ \\
9L2D & Mucor sp \\
\hline
\end{tabular}

\section{DISCUSSION AND CONCLUSION}

In the current study, a total of 44 fungi were isolated from six soil samples, and the focus is to choose fungi that have different characteristics. Fungal strains belonging to different genera and exhibited variation in protease activity. Isolates identified from their morphological characteristics, Aspergillus $s p$. colonies are green to gray and small, Rhizopus $s p$. has a large white settlement, Fusarium $s p$. also white, but a small colony, and Mucor sp. a colony of medium size white and yellow on the back.

Results of the clear zone around the isolates showed that Aspergillus sp. shows highest protease activity compared with other isolates in this study. The area formed by the digestion of proteins with multiple protease enzymes produced by the isolates, sources of protein are from skimmed milk added to it to determine the production of protease by strains, zone showed greater digestibility higher activity (Cappuccino \& Sherman, 2008). The protease enzymes activity increased from $48 \mathrm{hrs}$ to $96 \mathrm{hrs}$ of incubation and after the point that the production of enzyme was forced to stop because there is no increase in the emission zone is observed. This may be caused by nutrient stress, aging culture, accumulation of toxic end products, and moderate protein degradation by protease.

The Aspergillus niger showed maximum activity at a temperature of $27^{\circ} \mathrm{C}$, maximum protease production was also observed at $32^{\circ} \mathrm{C}$ is shown by the size of the zone around the colonies (Dubey et al., 2010). . The study found that the protease activity showed maximum activity at $\mathrm{pH}$ 6 media used for the experiment. Results clearly showed that the fungus isolated prefer a lower $\mathrm{pH}$ for growth and protease production. But in another study reported (Tharwat et al., 2014) that Aspergillus. fumigatus showed that the optimum $\mathrm{pH}$ is 11 . Hussain et al. (2010) have found that the optimum $\mathrm{pH}$ is from 7-11 for the production of serine protease by Aspergillus terreus. Optimum protease activity from Aspergillus oryzae was found at pH 8-9 (Samarntarn et al., 1999). In another study, the optimal $\mathrm{pH}$ of 7 has been reported to Aspergillus flavus (Dubey et al., 2010), but Ali (1992) have found that the optimum $\mathrm{pH}$ is 6 for the protease produced by Aspergillus fumigatus, it is similar to our study, the Aspergillus $s p$. protease showed the highest activity at $\mathrm{pH} 6$.

In the current study, a total of 44 fungi were isolated from six different samples, and the focus is to choose fungi that have different characteristics in order to avoid repeating the isolates from the soil surface and $15 \mathrm{~cm}$ deep. Fungal isolates belonging to different genera and variation exhibited in protease activity. Protease which has been produced from the isolated fungi, Aspergillus sp. isolated from the surface using room temperature $\left(27^{\circ} \mathrm{C}\right)$ provided high production in a relatively short incubation period.

Our research revealed that the fungi isolated from the soil in three different locations under banana trees has protease activity determined by skim milk agar method. Based on the microscopic observations, the 14L3S fungi isolate was identified as Aspergillus sp., then 6L1D fungi isolate was identified as Rhizopus $s p$, after that $5 \mathrm{~L} 2 \mathrm{~S}$ fungi isolate was identified as Fusarium $s p$., and 9L2D fungi was identified as Mucor sp. Aspergillus $s p$. resulted in the highest production of the active protease as indicated by the halo hydrolysis zone formed around the colony. This study has given a hint that microbial wealth of protease producing fungi isolated from soil can harness for biotechnological processes.

\section{REFERENCES}

1. Abe CA, Faria CB, de Castro FF, de Souza SR, Santos FC, da Silva CN, Tessmann DJ, BarbosaTessmann IP. Fungi isolated from maize (Zea mays L.) grains and production of associated enzyme activities. International journal of molecular sciences. 2015; 16(7):15328-46.

2. Aladdin A, Alsaheb RA, Pareek A, Othman NZ, Malek RA, El Enshasy HA. Biotechnological Aspects and Pharmaceutical Applications of Bacterial Proteases. Der Pharmacia Lettre. 2017; 9(2):9-20.

3. Ali OA. Formation of proteases by Aspergillus 
fumigatus and Pencillium sp. King Saud University-Science. 1992; 4(2):127-36.

4. Anitha TS, Palanivelu P. Purification and characterization of an extracellular keratinolytic protease from a new isolate of Aspergillus parasiticus. Protein expression and purification. 2013; 88(2):214-20.

5. Anitha TS, Palanivelu P. Production and characterization of keratinolytic protease (s) from the fungus, Aspergillus parasiticus. International Journal of Research in Biological Sciences. 2012; 2:87-93.

6. AZAZ AD. Investigation of the Microfungal Flora of the Bird Paradise National Park in Bandýrma, Balýkesir (Turkey). Turkish Journal of Biology. 2003 May 5; 27(2):117-23.

7. Ayob FW, Simarani K. Endophytic filamentous fungi from a Catharanthus roseus: Identification and its hydrolytic enzymes. Saudi Pharmaceutical Journal. 2016; 24(3):273-8.

8. Bradner JR, Gillings $M$, Nevalainen KM. Qualitative assessment of hydrolytic activities in Antarctic microfungi grown at different temperatures on solid media. World Journal of Microbiology and Biotechnology. 1999; 15(1):131-2.

9. Cappuccino JG, Sherman N. Microbiology: A laboratory Manual. (Tenth Edit). Boston: Pearson Education; 2008.

10. Choudhary V, Jain PC. Isolation and identification of alkaline protease producing fungi from soils of different habitats of Sagar and Jabalpur District (MP). J. Acad. Indus. Res. 2012; 1(3):106.

11. Dubey, R., Adhikary, S., Kumar, J., \& Sinha, N. Isolation, Production, Purification, Assay and Characterization of Alkaline Protease Enzyme from Aspergillus Niger and Its Compatibility with Commercial Detergents. Developmental Microbiology and Molecular Biology. 2010; 1(1), 75-94.

12. El Enshasy H. Production of Cysteine Proteases by Recombinant Microorganisms: A Critical Review. Yeast. Journal of Pharmacy and Biological Sciences. 2016; 11(2) 35-40.

13. Germano S, Pandey A, Osaku CA, Rocha SN, Soccol CR. Characterization and stability of proteases from Penicillium sp. produced by solid-state fermentation. Enzyme and microbial technology. 2003; 32(2):246-51.

14. Hankin L, Anagnostakis SL. The use of solid media for detection of enzyme production by fungi. Mycologia. 1975; 1:597-607.

15. Holt JG. Krieg. NR, Sneath, PHA, Staley, JT, dan William, ST. Bergey's Manual of Determinative Bacteriology. 1994 (W. R. Hensyl, Ed.) (Ninth
Edit). Philadelphia: Lippincott Williams \& Wilkin. 16. Hussain A, Manan A, Zubair H, Mirza B. Purification and characterization of alkaline proteases from Aspergillus terrus. J. Chem. Soc. Pak. 2010; 32(4):497-504.

17. Jisha VN, Smitha RB, Pradeep S, Sreedevi S, Unni KN, Sajith S, Priji P, Josh MS, Benjamin S. Versatility of microbial proteases. Advances in enzyme research. 2013; 1(03):39.

18 Kumar L, Jain SK. A Review on Environmental Pollution Mitigation by Fungal Proteases. Research \& Reviews: A Journal of Microbiology and Virology. 2017; 7(3):32-7.

19. Kumari $M$, Sharma A, Jagannadham MV. Religiosin B, a milk-clotting serine protease from Ficus religiosa. Food chemistry. 2012; 131(4):1295-303.

20. Kutateladze LY, Zakariashvili NG, Jobava MD, Burduli TA, Sadunishvili TA. Microscopic fungi spread in different types of soils in Western Georgia. Annals of Agrarian Science. 2016; 14(3):227-32.

21. Leck A. Preparation of lactophenol cotton blue slide mounts. Community Eye Health. 1999; 12(30):24.

22. Malloch D. Moulds, their isolation, cultivation, and identification. University of Toronto Press. 1981.

23. Mohanasrinivasan V, Shankar V, Elizabeth R, Soumya AR, Devi CS. Isolation, screening and identification of protease producing fungi from rhizosphere soil and optimisation of $\mathrm{pH}$, incubation time and inducer concentration for enhanced protease production. International Journal of Pharma and Bio Sciences. 2012; 3(2):784-793.

24. Namasivayam SK, Nirmala D. Evaluation of organic waste liquor media for the production of alpha amylase using Aspergillus niger. Peak J. Biotechnol. 2013; 1(2):7-11.

25. Oyeleke SB, Egwim EC, Auta SH. Screening of Aspergillus flavus and Aspergillus fumigatus strains for extracellular protease enzyme production. Journal of Microbiology and Antimicrobials. 2010; 2(7):83-7.

26. Paul T, Jana A, Mandal AK, Mandal A, Mohpatra PK, Mondal KC. Bacterial keratinolytic protease, imminent starter for NextGen leather and detergent industries. Sustainable Chemistry and Pharmacy. 2016; 3:8-22.

27. Pailin T, Kang DH, Schmidt K, Fung DY. Detection of extracellular bound proteinase in EPS producing lactic acid bacteria cultures on skim milk agar. Letters in applied microbiology. 2001; 33(1):45-9. 
28. Prassas I, Eissa A, Poda G, Diamandis EP. Unleashing the therapeutic potential of human kallikrein-related serine proteases. Nature Reviews Drug Discovery. 2015; 14(3):183.

29. Samarntarn W, Cheevadhanarak S, Tanticharoen M. Production of alkaline protease by a genetically engineered Aspergillus oryzae U1521. The Journal of general and applied microbiology. 1999; 45(3):99-103.

30. Sabotiè J, Kos J. Microbial and fungal protease inhibitors-current and potential applications. Applied microbiology and biotechnology. 2012; 93(4):1351-75.

31. Sawant R, Nagendran S. Protease: an enzyme with multiple industrial applications. World Journal of Pharmacy and Pharmaceutical Sciences. 2014; 3(6):56879.

32. Sharpley, J. M. Elementary Petroleum Microbiology. Texas. Houston: Gulf Publishing Company Houston 1966.

33. Souza PM, Bittencourt ML, Caprara CC, Freitas MD, Almeida RP, Silveira D, Fonseca YM, Ferreira Filho EX, Pessoa Junior A, Magalhães PO. A biotechnology perspective of fungal proteases. Brazilian Journal of Microbiology. 2015; 46(2):337-46.

34. Tarman K, Lindequist $U$, Wende K, Porzel A, Arnold N, Wessjohann LA. Isolation of a new natural product and cytotoxic and antimicrobial activities of extracts from fungi of Indonesian marine habitats. Marine drugs. 2011; 9(3):294306.

35. Tharwat N, Sayed MA, Fadel HM. Biochemical and molecular characterization of alkalothermophilic proteases purified from Aspergillus fumigatus. J Biol Chem Res. 2014; 31:236-52.

36. Vishwanatha, K. S., Rao, A., \& Singh, S. Characterisation of Acid Protease Expressed From Aspergillus Oryzae MTCC 5341. Food Chemistry. 2009; 114(2), 402-407.

37. Vishwanatha KS, Rao AA, Singh SA. Production and characterization of a milk-clotting enzyme from Aspergillus oryzae MTCC 5341. Applied microbiology and biotechnology. 2010; 85(6):1849-59.

38. Vijayaraghavan P, Vincent SG. A simple method for the detection of protease activity on agar plates using bromocresolgreen dye. Journal of Biochemical Technology. 2013; 4(3):628-30.

39. Warcup JH. The soil-plate method for isolation of fungi from soil. Nature. 1950; 166(4211):117.

40. Waksman SA. A method for counting the number of fungi in the soil. Journal of bacteriology. 1922; 7(3):339.

41. Willey, J. M., Sherwood, L. M., \& Woolverton, C. J. (2009). Prescott's Principles of Microbiology. New York, NY: Mcgraw-Hill Higher Education.

42. $\mathrm{Xu} \mathrm{X,} \mathrm{Yan} \mathrm{H,} \mathrm{Chen} \mathrm{J,} \mathrm{Zhang} \mathrm{X.} \mathrm{Bioactive} \mathrm{proteins}$ from mushrooms. Biotechnology advances. 2011; 29(6):667-74. 